\title{
Introductory measurements on the physical model of the VVER 440 nuclear reactor II. fuel cell assembly
}

\author{
Zdenko Závodný ${ }^{1}$, Peter Mlynár ${ }^{1}$, František Urban $^{1}$, Ján Hollý ${ }^{1}$, Zoltán Fuszko ${ }^{1}$, and \\ František Világi ${ }^{1}$ \\ ${ }^{1}$ Slovak University of Technology in Bratislava, Faculty of Mechanical Engineering, Institute of \\ Energy Machinery, Nám. slobody 17, 81231 Bratislava, Slovakia
}

\begin{abstract}
Qualitative and quantitative analysis of the relationship between the coolant temperature in the fuel cell assembly outlet and the mean coolant temperature profile in the thermocouple plane is required for safe and effective loading of nuclear fuel cells. Physical model of the VVER 440 nuclear reactor fuel cell assembly serves to analyze the influence of the coolant mass flow on the coolant velocity and temperature profiles at the plane of the thermocouple position in the fuel cell assembly.
\end{abstract}

\section{Introduction}

During the operation of the VVER 440 pressurized water reactor, uneven development of the heat in the assemblies occurs because of the burn-out and the placement of the individual fuel cell assemblies in the active zone of reactor. Heat generation is also uneven in the fuel rods, therefore an uneven temperature profile of the coolant is present at the fuel rods outlet. The coolant flows further through the alignment grid. In addition to the change in the shape of the cross-sectional area from the hexagonal to the circular, the size of the flow area also varies at the outlet from the assembly. The temperature profile of the coolant flow is equalized. Further mixing of the coolant takes place during its flow in the inlet of the protective tube block. The coolant temperature at the fuel cell assembly outlet is measured by a thermocouple which is located in the fuel cell assembly axis about $300 \mathrm{~mm}$ from the end of the fuel rods. Qualitative and quantitative analysis of the relationship between the coolant temperature in the fuel cell assembly outlet and the mean coolant temperature profile in the thermocouple plane is required for safe and effective loading of nuclear fuel cells [1].

\section{Physical models of VVER 440 fuel cell assembly}

In the laboratory of the Institute of Energy Machinery of the Faculty of Mechanical Engineering STU in Bratislava are the experimental models of I. and II. fuel cell assembly of VVER 440 nuclear power plant. The dimensions of the available production drawings

\footnotetext{
$\overline{{ }^{*} \text { Corresponding author: peter.mlynar@stuba.sk }}$
} 
and documentation of the reactor V 213 of the nuclear power plant with the pressurized water reactor VVER 440 were used to create the fuel cell assembly models. The physical models are used to analyze the water flow in the outlet portion of the fuel cell assembly of the nuclear reactor.

\subsection{Physical model of VVER 440 I. fuel cell assembly}

The fuel cartridges are replaced with $8 \mathrm{~mm}$ diameter aluminium and copper pipes in the experimental models. The diminished physical model of the real object - fuel cell assembly of reactor V 213 of nuclear power plant VVER 440 - was created in scale 1:1.125. In this case we are talking about the geometric similarity between the model and the real object. The heated water in the fuel cell assembly flows around the fuel cartridges. The fuel cartridges in the physical fuel cell model are formed of 117 aluminium tubes with closed sides alongside with 3 triple copper tubes. With these triple copper tubes, cool water can be fed to the model. In the plane of the end of fuel cartridges the mixing of heated and cold water takes place. In this way, the temperature field is modeled at the outlet of the fuel cartridges.

Temperature and velocity profiles are measured with 2 combined probes located in 3 planes at the outlet of the fuel cell assembly physical model (Figure 1):

- The plane 1 is situated between the end of the fuel rod bundle and mixing grid.

- The plane 2 is situated behind the mixing grid and the ending of the central tube at the beginning of the cylindrical head of fuel cell assembly outlet.

- Plane 3 is at the position of thermocouple of the nuclear reactor fuel cell assembly $[2,4]$.

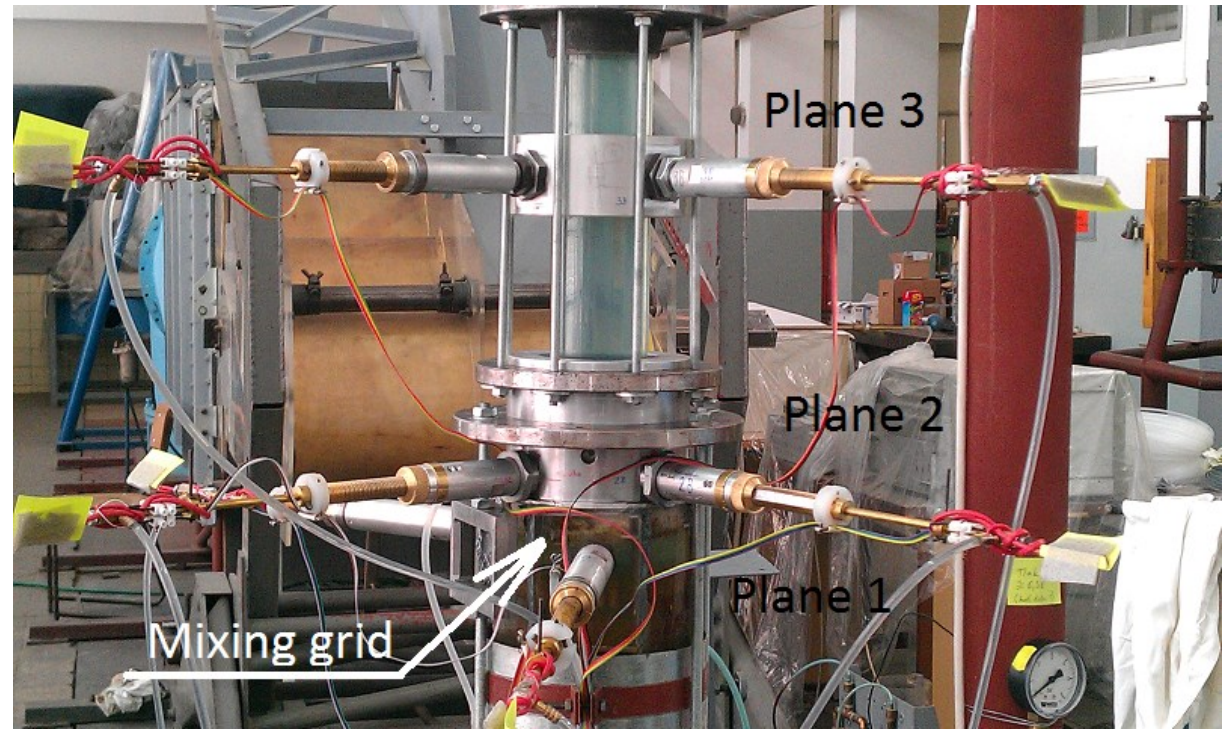

Fig. 1. The outlet of I. fuel cell assembly physical model with combined probe traverse devices located in planes 1,2 and 3 .

\subsection{Physical model of VVER 440 II. fuel cell assembly}

Based on the analysis of the measurement result of coolant mixing in the outlet portion of the I. fuel cell assembly and the published CFD simulations $[5,6]$ it has been shown, that the dependence of the water flow through a centralized tube on the temperature and 
velocity field of the coolant in the plane 3 has to be discussed in detail. For this reason, an experimental device with the II. fuel cell assembly physical model of the nuclear reactor VVER 440 was designed, manufactured and presented. The II. physical model is simplified. It consists of a circular section of the fuel cell assembly of the reactor VVER 440. The casing of the fuel cell assembly with inner diameter $\varnothing 81.7 \mathrm{~mm}$ is fitted with 30 fuel cartridges $\varnothing 9.53 \mathrm{~mm}, 6$ fuel cartridges $\varnothing 6 \mathrm{~mm}$ at the casing itself, and with a $\varnothing 11 \mathrm{~mm}$ central tube (Figure 2). The fuel cartridges of $2770 \mathrm{~mm}$ length are vertically positioned using 11 simplified spacing grids. The central tube is closed from the bottom side. The holes in the central tube are used to hold the spacing grids and at the same time the water is pumped through them to the fuel cell assembly. The mixing grid is mounted to the upper side of the central tube (Figure 3). The dimensions of the II. fuel cell assembly physical model are scaled in 1.068 compared to the fuel cell assembly of the reactor VVER 440.

The experimental device with the II. fuel cell assembly physical model consists of a pump with frequency converter, a fuel cell assembly, an inlet and drainage pipe and a circuit for adding cold water to the water stream flowing through the fuel cell assembly model. Hot and cold water is fed to the experimental device from a public water supply network. The velocity profile in plane 0 , located $2900 \mathrm{~mm}$ from the pump, on the physical model inlet is measured by two Pitot probes. In planes 1, 2 and 3 are 8 combined probes located and used to measure temperatures and water flow velocities. There is a set of pressure transducers, resistive thermometers and water flow diaphragm available.

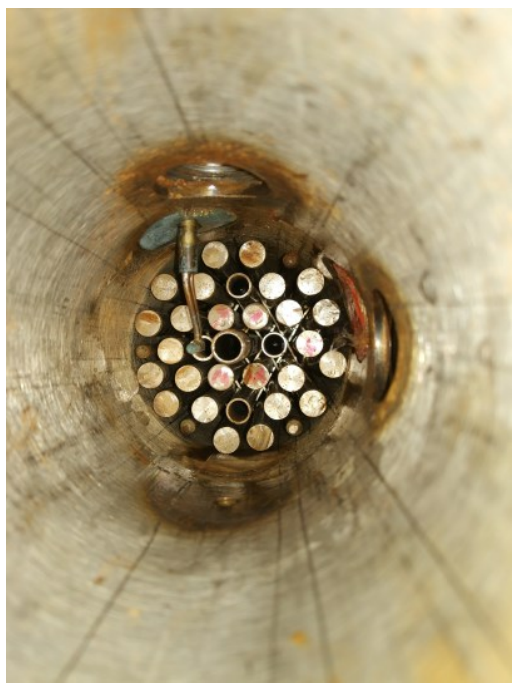

Fig. 2. Outlet of the II. fuel assembly physical model - upper end of the fuel cartridges, central tube and combined probe in plane 1.

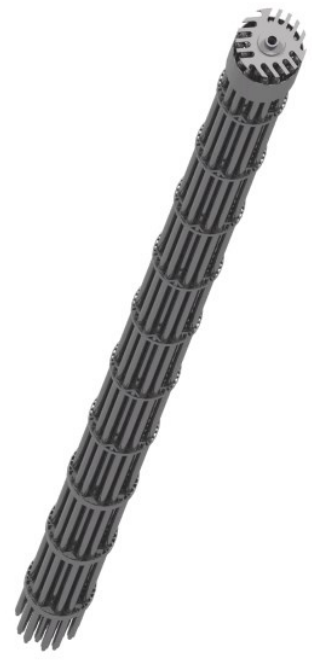

Fig. 3. Fuel cartridges, spacing grids, alignment grid and the central tube of the II. fuel cell assembly model.

\section{Physical similarity of water flow in physical models of fuel cell assemblies I, II. and the fuel cell assembly VVER 440 reactor}

Cooling water mass flow through the fuel cell assembly located in the VVER 440 nuclear power plant is $26.31 \mathrm{~kg} . \mathrm{s}^{-1}$. The coolant flow at the fuel cell assembly outlet has the temperature $300{ }^{\circ} \mathrm{C}$. In the plane of the thermocouple location this flow can be characterized by Reynolds number Re 4,735 $\times 10^{6}$ (Table 1). 
Both fuel cell assembly physical models can be operated with water temperatures up to $60{ }^{\circ} \mathrm{C}$. This is due to the way of heating the water in the condensing boiler for the physical model of the I. fuel cell assembly and the centrally prepared hot water for the physical model of the II. fuel cell assembly. High values of the dynamic viscosity $\eta$ of water flowing in the I. and II. fuel cell assembly physical models. $\left(6.530 \times 10^{-4} \mathrm{~Pa} . \mathrm{s}\right.$ and $\left.4.664 \times 10^{-4} \mathrm{~Pa} . \mathrm{s}\right)$ reduce the value of the Reynolds number $\operatorname{Re}\left(2.979 \times 10^{5}\right.$ and $3.033 \times 10^{5}$, Table 1.). When analysing the results of measurements on the I. and II. fuel cell assembly physical models, we focus at determining the influence of water flow rate $\mathrm{m} \mathrm{cl}$, flow velocity $v$, dynamic viscosity $\eta$ and relative roughness of the pipeline $k / d$ on the Reynolds number $R e$ and on the velocity and temperature profiles in plane 3 at the outlet of the assembly, at the same simulated inequality temperature profile in plane 1. In Figure 4 is a Moody diagram showing the values of the friction loss coefficient $\lambda$ depending on the Reynolds number $R e$ and the relative roughness $k / d$ of the VVER 440 nuclear reactor fuel cell assembly (point 1), the physical model of fuel cell assembly I. (point 2) and the physical model of fuel cell assembly II. (point 3). For the strictly turbulent region, the friction loss coefficient $\lambda$ depends only on the relative roughness rather than value of the Reynolds number. The lower the relative roughness, the lower the Reynolds number. The values $R e$ of the Reynolds number and the friction loss coefficient $\lambda$ for the real fuel cell assembly are located in the strictly turbulent region (point 1). Measurements of velocity and temperature profile in the I and II. fuel cell assembly models are carried out near the automotive flow region where the friction loss coefficient $\lambda$ is close to the constant value (points 2 and 3 ). As a consequence of keeping the dimensional and physical similarities between the VVER 440 reactor fuel cell assembly and the fuel cell assembly models I. II. the results of measurements in the model are in accordance with the real flow of the coolant at the fuel cell assembly outlet [7].

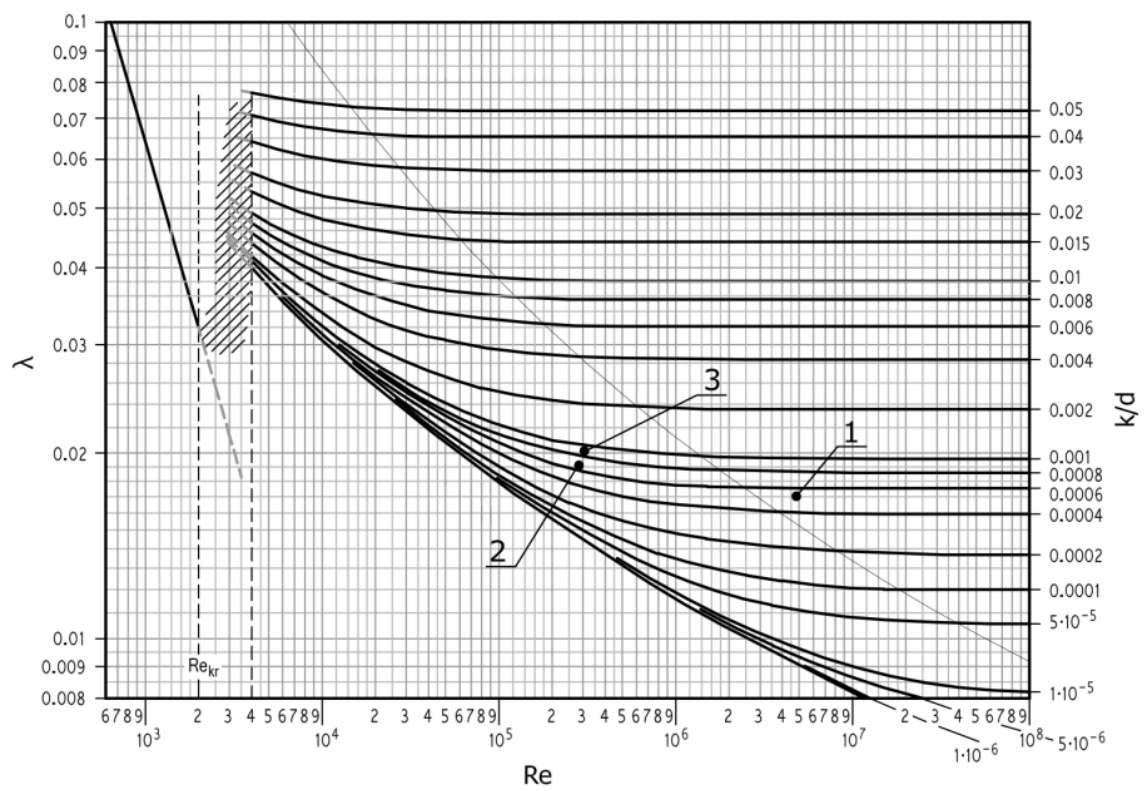

Fig. 4. Friction loss coefficient $\lambda$ according to Reynolds number $R e$ and relative roughness $k / d$ 1 VVER 440 real fuel cell assembly,

2 I. fuel cell assembly physical model,

3 II. fuel cell assembly physical model. 
Table 1. Values of the relative roughness $k / d$ and Reynolds number $R e$ measured in plane 3 of VVER 440 real fuel cell assembly and the I. and II. fuel cell assembly models.

\begin{tabular}{|c|c|c|c|c|c|c|c|c|c|}
\hline \multirow{2}{*}{ Fuel cell assembly } & $p$ & $t$ & $\rho$ & $\eta$ & $d$ & $m c l$ & $v$ & $\operatorname{Re}$ & $k / d$ \\
\hline & (MPa) & $\left({ }^{\circ} \mathrm{C}\right)$ & $\left(\right.$ kg.m $\left.{ }^{-3}\right)$ & (Pa.s) & (m) & $\left(\mathrm{kg} \cdot \mathrm{s}^{-1}\right)$ & $\left(\mathrm{m} \cdot \mathrm{s}^{-1}\right)$ & $(-)$ & $(-)$ \\
\hline VVER 440 & 12.3 & 300 & 720.17 & $8.734 \mathrm{E}-05$ & 0.081 & 26.31 & 7.09 & $4.735 \mathrm{E}+06$ & 0.00056 \\
\hline Physical model I & 0.3 & 40 & 992.31 & $6.530 \mathrm{E}-04$ & 0.072 & 11.00 & 2.72 & $2.979 \mathrm{E}+05$ & 0.00063 \\
\hline Physical model II & 0.3 & 60 & 983.30 & 4.664E-04 & 0.054 & 6.00 & 2.66 & $3.033 \mathrm{E}+05$ & 0.00083 \\
\hline
\end{tabular}

\section{Initial measurements on the II. fuel cell assembly physical model of the VVER 440 nuclear reactor}

Experimental device with II. fuel cell assembly physical model should be designed considering the balance of velocity profile in the plane 0 at the fuel cell assembly inlet. The initial measurements are aimed at detecting the velocity profile measured by Pitot probes $\mathrm{A} 0$ and $\mathrm{B} 0$ in the range of water flow rates $m_{\mathrm{cl}}$ of the assembly. It is also necessary to determine the dependence of the pressure loss $\Delta p$ kaz of the II. fuel cell assembly physical model from the water flow rate $m$ cl measured by flow diaphragm. In the next phase of experiments, coolant mixing in the output part of the II. fuel cell assembly physical model will be analyzed. By pair of combined probes, the temperature and velocity profiles will be measured in plane 1: after the end of the fuel rods, plane 2: behind the alignment grid and plane 3: in the plane of the thermocouple placement in the VVER 440 reactor fuel cell assembly. Figure 5 is an example of the measured values on the computer during the initial measurement on the fuel cell assembly physical model of nuclear reactor.

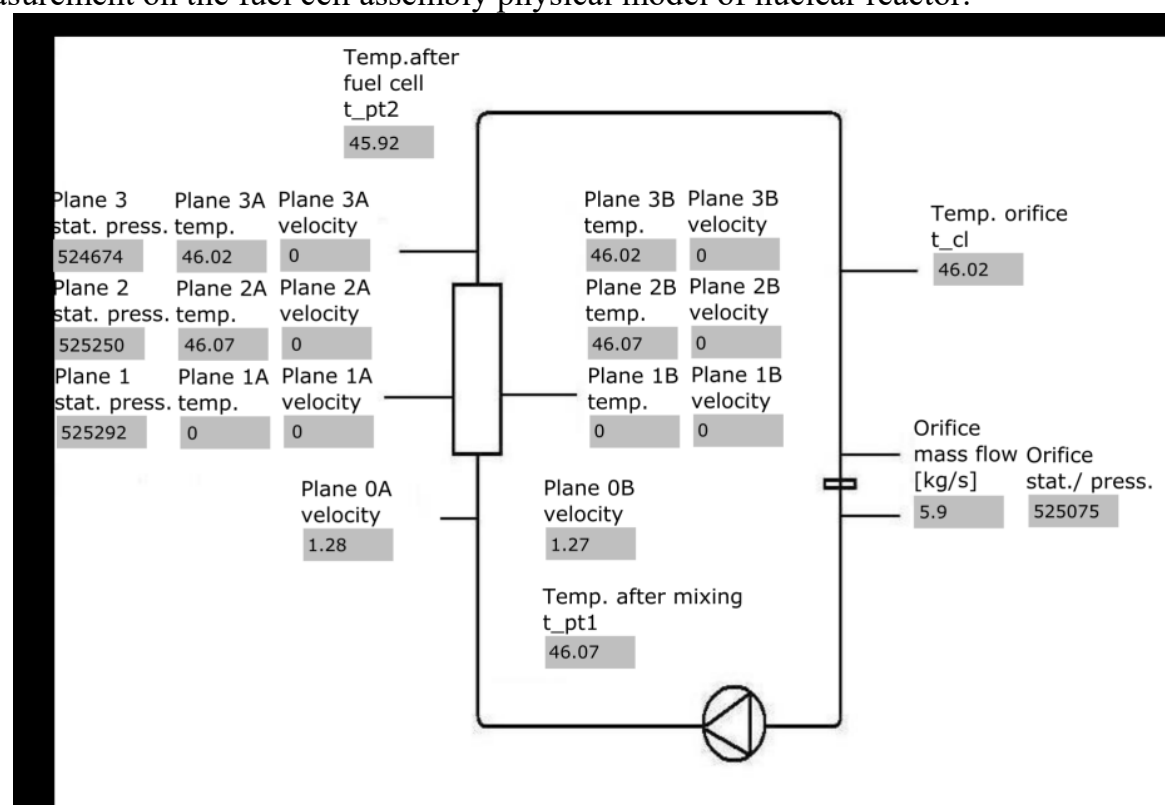

Fig. 5. Representation of the measured values on the computer screen during the initial measurement on the II. fuel cell assembly physical model of the VVER 440 nuclear reactor. 


\subsection{Pressure loss of the II. fuel cell assembly physical model}

The pressure loss of the II. fuel cell assembly physical model is measured as the difference between two static pressures before and behind the assembly. Sampling is carried out on pipes of the same diameter $\varnothing 82 \mathrm{~mm}$. At water flow rates from $1.91 \mathrm{~kg} . \mathrm{s}^{-1}$ to $5.44 \mathrm{~kg} . \mathrm{s}^{-1}$, the pressure loss was between $10.297 \mathrm{kPa}$ and $65.879 \mathrm{kPa}$ (Figure 6).

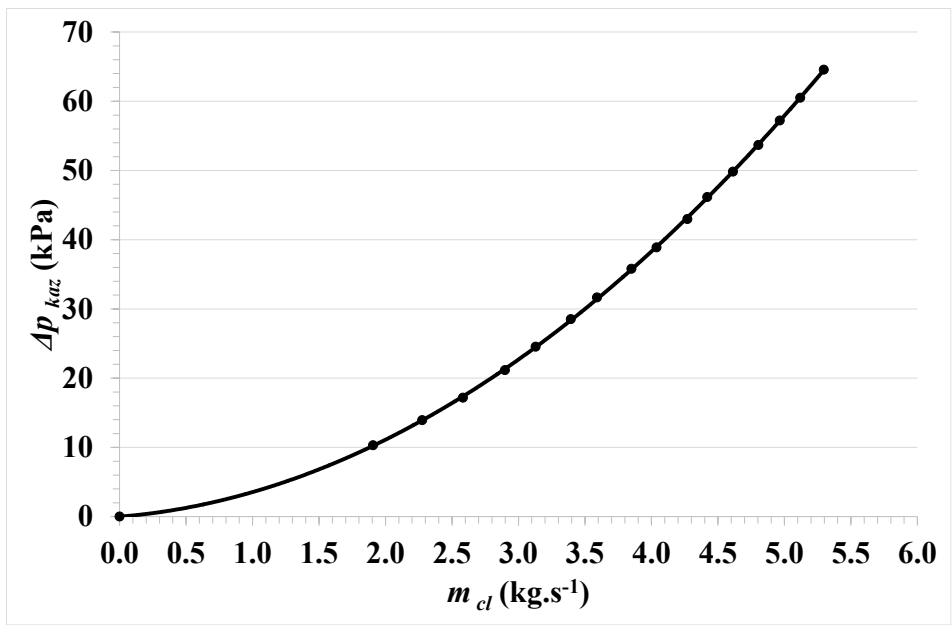

Fig. 6. Pressure loss $\Delta p$ kaz of the II. fuel cell assembly physical model depending on the water flow rate.

\subsection{Velocity profile in plane 0 at II. fuel cell assembly physical model water inlet}

The velocity profile in plane 0 of inlet to the fuel cell assembly physical model is measured by two Pitot probes A0 and B0 that are installed in the traversing devices. The water flow velocity $v_{S R}$, measured by probe $\mathrm{S}(\mathrm{S}=\mathrm{A}$ for probe $\mathrm{A} 0$, and $\mathrm{S}=\mathrm{B}$ for probe $\mathrm{B} 0)$; in the plane $\mathrm{R}(\mathrm{R}=0)$ at probe position $i$ is calculated from the dynamic pressure $p_{d i}$ measured at point $i$ and the density of water $\rho_{v}$ by this equation:

$$
v_{S R i}=\sqrt{\frac{2 \cdot p_{d i}}{\rho_{v}}}
$$

Velocity profiles of the water flow in the pipe $(\Phi 82 \mathrm{~mm})$ at the inlet to the II. fuel cell assembly model which were measured by probes A0 and B0 are shown in Figure 7 up to Figure 10. Water flow at the inlet of the assembly can be evaluated as turbulent, axially symmetrical.

By integrating the velocity profiles measured by probes $\mathrm{A} 0$ and $\mathrm{B} 0$, the flows were determined

$$
m_{\text {traverz } A 0 \text { r } \varepsilon\langle 0,|-41|\rangle}, m_{\text {traverz } A 0 \operatorname{r} \varepsilon\langle 0,41\rangle}, m_{\text {traverz } B 0 \operatorname{r} \varepsilon\langle 0,|-41|\rangle}, m_{\text {traverz } B 0 \operatorname{re}\langle 0,41\rangle} .
$$

From these four values, an average value of the flow rate was calculated $\mathrm{m}_{\text {traverz }}$.

Flow rate $m_{\text {traverzAOr } \varepsilon(0,41)}$ is calculated by equation:

$$
m_{\text {traverz } A 0 r \varepsilon\langle 0,41\rangle}=\sum_{i=2}^{21} 2 . \pi \cdot \rho \int_{r i-1}^{r i} \mathcal{v}_{A 0 i}(r) \cdot r \cdot d r=\sum_{i=2}^{21} 2 . \pi \cdot \rho \int_{r i-1}^{r i}\left(\alpha_{v 1 i} \cdot r+\alpha_{v 0 i}\right) \cdot r \cdot d r,(3)
$$

points $v_{S R i-1}\left(r=r_{S R i-1}\right)$ and $v_{\mathrm{SR}}\left(r=r_{S R i}\right)$ was used to determine the equation of a line 


$$
v_{S R i}(r)=\alpha_{v 1 i} \cdot r+\alpha_{v 0 i}
$$

After the adjustment we get

$$
m_{\text {traverz } A 0 \mathrm{r} \varepsilon\langle 0,41\rangle}=2 . \pi \cdot \rho \sum_{i=2}^{21}\left[\frac{\alpha_{v 1 i} \cdot r^{3}}{3}+\frac{\alpha_{v 0 i} \cdot r^{2}}{2}\right]
$$

In the same way, we calculate the flows

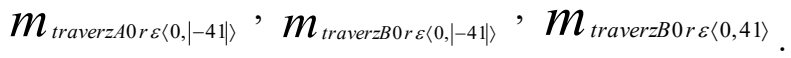

Table 2 shows water flow rates $m_{\text {traverz }}$ at the inlet of the II. fuel cell assembly model, calculated by integrating the velocity profiles measured by Pitot probes A0 and B0. The relative deviation of the flow rates $\left(m_{c l}-m_{\text {traverz }}\right) / m c l$ from the flow rates $m_{c l}$ measured by the flow diaphragm was $-2.21 \%$ to $-6.06 \%$.

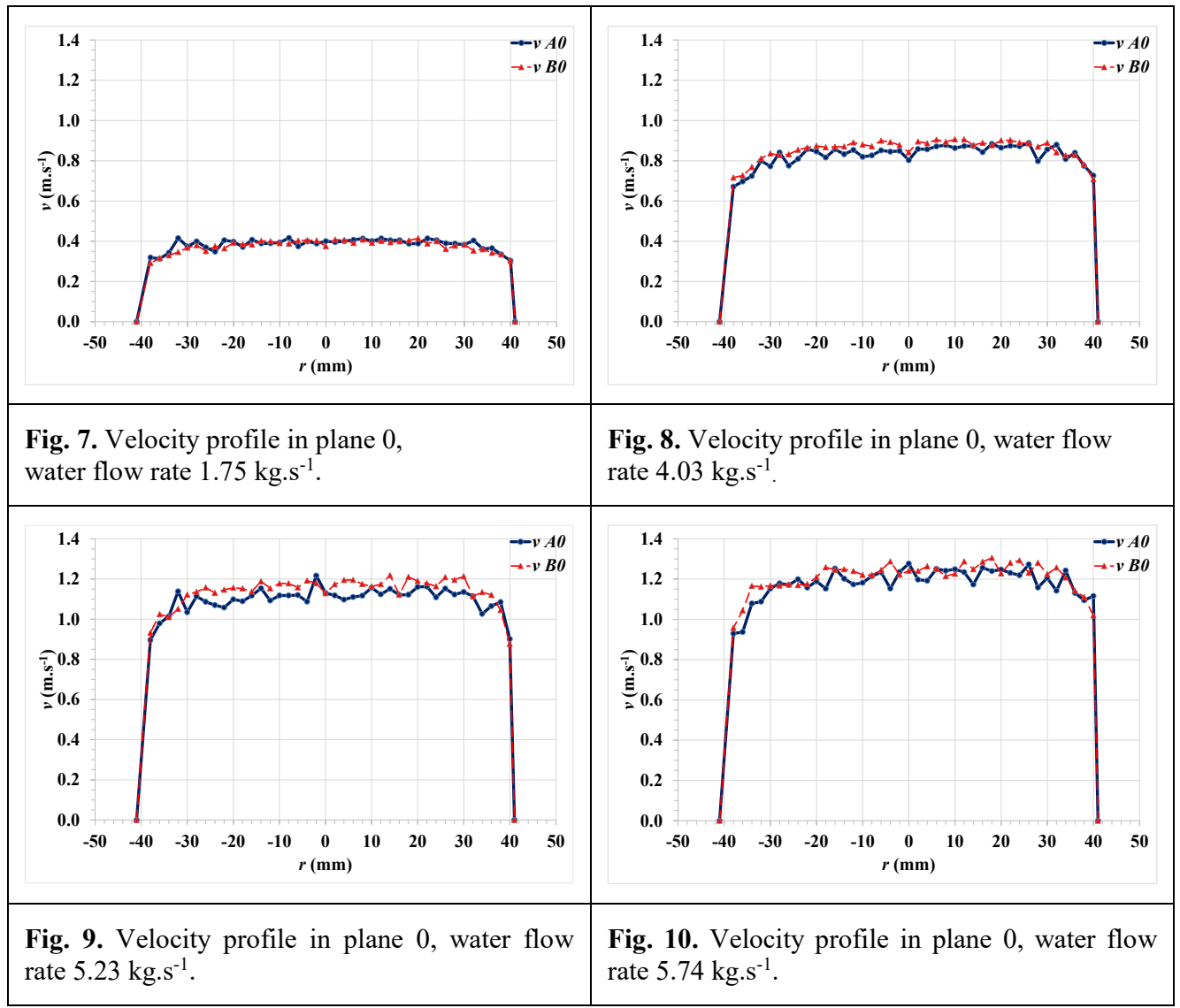

Table 2. II. fuel cell assembly physical model water flow rate comparison $m_{\text {traverz }}$ and $m_{\mathrm{cl}}$.

\begin{tabular}{|l|c|c|c|c|c|}
\hline$m_{\text {traverz }}$ & $\left(\mathrm{kg} . \mathrm{s}^{-1}\right)$ & 1.85 & 4.13 & 5.46 & 5.87 \\
\hline$m_{c l}$ & $\left(\mathrm{~kg} . \mathrm{s}^{-1}\right)$ & 1.75 & 4.03 & 5.23 & 5.74 \\
\hline$\left(m_{c l}-m_{\text {traverz }}\right) / m_{c l} * 100$ & $(\%)$ & -6.06 & -2.51 & -4.22 & -2.21 \\
\hline
\end{tabular}




\section{Conclusion}

By measuring the velocity profile in plane 0 at the inlet of the fuel cell assembly it was confirmed, that the water flow is turbulent and axially symmetrical.

As a consequence of keeping the dimensional and physical similarities between the VVER 440 reactor fuel cell assembly and the fuel cell assembly models I. II. the results of measurements in the model are in accordance with the real flow of the coolant at the fuel cell assembly outlet.

For the future variants of the water mixing measurements at the output part of the II. physical model the CFD simulation will have to be performed to simulate the water flow.

The task will be to select a suitable method for CFD simulation to model the turbulence and generate a computational mesh with respect to measurement results on the physical model. After that the CFD calculations can be adjusted in such a manner that the measured temperature and velocity profiles in the plane 1 can be replaced by the profiles calculated for the real distribution of the heat output of the individual fuel rods in the VVER 440 nuclear reactor fuel cell assembly.

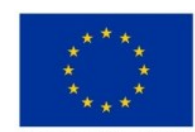

Európska únia

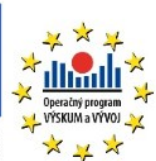

This contribution was created on the basis of the project "Research centre ALLEGRO" (ITMS project code: 26220220198), supported by Operational Programme Research and Development funded by the European Regional Development Fund.

\section{References}

1. L.L. Kobzar, D.A. Oleksyuk, Experiments on Simulation of Coolant Mixing in Fuel Assembly Head and Core Exit Channel of Assembly Head (AER on VVER Reactor Physics and Reactor Safety, 2006)

2. J. Bereznai, F. Urban, L'. Kučák, Engineering Mechanics, 20, 195-204 (2013)

3. F. Urban, L'. Kučák, J. Bereznai, M. Pulmann, J. Tihányi, Communications 14, 42-46 (2012)

4. F. Urban, L'. Kučák, J. Bereznai, Z. Závodný, P. Muškát, American Institute of Physics Publising LLC 1608 249-252 (2014)

5. S. Tóth, A. Aszódi, Detailed Analysis of Coolant Mixing in VVER-440 Fuel Assembly Heads (AER on VVER Reactor Physics and Reactor Safety, 2008)

6. J. Jakubec, V. Kutiš, E. Mojto, Study of mixing grid positioning in fuel assembly of VVER-440, (International Scientific Conference EEE 1 103-106 2014)

7. M. Čarnogurská, Základy matematického modelovania v mechanike tekutín a termodynamike (Vienala, Košice, 2000) 